\title{
Taiwanese University Students’ Expectations of Ideal English Class Lessons
}

\author{
Abolfazl Shirban Sasi ${ }^{1, *} \&$ Toshinari Haga ${ }^{1}$ \\ ${ }^{1}$ Department of Applied Foreign Languages, TransWorld University, Taiwan \\ *Correspondence: Department of Applied Foreign Languages, TransWorld University, Taiwan. E-mail: \\ Pictologics@gmail.com
}

Received: March 14, 2018

Accepted: March 25, 2018 Online Published: March 27, 2018

doi:10.5430/wjel.v8n1p37

URL: https://doi.org/10.5430/wjel.v8n1p37

\begin{abstract}
Learning English is a basic requirement amongst Taiwanese university students. A detailed scrutiny of what activities in an English class are more attractive to this need-to-be productive population would prove very useful to the education authorities. Thus, the current study has focused on the university students' opinion on the ideal English class. The participants were 446 students from TransWorld University. A 10-item multiple-choice questionnaire based on Littlewood (2010) was the instrument. The results revealed that girls and boys showed significant differences in their preference for English language activities. However, they had almost equal stand towards usage of language games and emphasis on correct pronunciation. Also, both genders showed the highest interest in a relaxed class atmosphere; and the lowest interest in the usage of smart phones in the class activities. Moreover, EFL-major students shared many common expectations with students of College of Hospitality and Tourism; and the least with the students of College of Management.
\end{abstract}

Keywords: activities, communicative, DAFL, EFL, ideal

\section{Introduction}

There is no doubt that learning the English language and culture has been flourishing continuously around the world. In Taiwan, apart from numerous needs for official international English proficiency certificates (such as IELTS, TOEFL, TOEIC, etc.), as well as certain English credit hours that each university student is supposed to pass, it may also be assumed that one very reliable indication of how much Taiwanese people would like to learn English can be observed in the Internet applications. For instance, as pertinent to the current research, the authors investigated "Taiwan Language Exchange - Taiwanese Language Partners" (a website which helps users make friends with the native speakers of certain languages in order to practice and learn the language). Almost all of the main and official languages spoken in the world are listed on this site's menu. For the sake of brevity, the authors examined the six current official and working languages of the United Nations namely, Arabic, Chinese, English, French, Russian, and Spanish; as well as the official languages of the ASEAN countries- some of the most important trade partners of Taiwan (Shirban Sasi, 2014) - namely, Burmese, Cambodian, Filipino (Tagalog), Indonesian, Lao, Malay, Thai, and Vietnamese. Thus, as of 1st of February, 2018, the statistics on 13 highly preferred languages by the Taiwanese were listed and ranked in Table 1.

It should be noticed that the number 67700 which signifies the total, is not an accumulation of the numbers associated to all of languages in this table because many users have chosen more than one language to learn. Moreover, there are some other languages which the users have selected. Then, as evident in Table 1, English by far is the most sought for language to learn among Taiwanese people. Moreover, a further scrutiny about this website and the users' photos and their messages reveals that they are mostly either teenagers or in their early 20 's. Thus, the current study which tries to find out the ideal English class from the Taiwanese students' perspective could illustrate as to what kind of English language classroom activities can help the Taiwanese language learners benefit more from their time and energy in the class and, eventually, help them reach their goal of learning English. 
Table 1. Highly Preferred Languages to Learn by the Taiwanese

\begin{tabular}{ccc}
\hline Rank & Language & Number \\
\hline 1 & English & 52541 \\
2 & French & 6347 \\
3 & Spanish & 5120 \\
4 & Russian & 1015 \\
5 & Thai & 911 \\
6 & Vietnamese & 572 \\
7 & Arabic (Middle Eastern) & 247 \\
8 & Filipino (Tagalog) & 232 \\
9 & Indonesian (Bahasa) & 213 \\
10 & Cambodian (Khmer) & 198 \\
11 & Burmese & 174 \\
12 & Malay (Bahasa Malaysia) & 115 \\
13 & Lao & 15 \\
& Total & $\mathbf{6 7 7 0 0}$
\end{tabular}

Note: Total is not accumulative.

\section{Review of Literature}

There are several studies addressing students' opinion about classroom activities. For example, Green (1993) investigated students' expectations regarding the effectiveness of communicative and non-communicative activities. He administered a 17-item questionnaire. The data revealed that the students almost similarly weighed the activities that emphasized formal correctness and those activities that stressed real use of language. Rao (2002) also showed that language learners might prefer a combination of traditional and communicative activities. He applied a case study to investigate Chinese university students' perceptions of communicative and non-communicative activities. He studied 30 EFL Chinese students and examined their opinions using a questionnaire and a semi-structured interview. The data suggested that Chinese students favored non-communicative activities over communicative ones. The students also liked traditional activities more, and thought they were more effective. Rao further recommended language instructors to make use of a combination of communicative and non-communicative activities. According to Spratt (2001) who studied 997 university students in Hong Kong, it is crucial to know students' preferences in planning syllabuses and designing materials. Also, Nunan's (1996) study highlighted the learning-centered lesson plans in which learners have a role in selecting what classroom activities they wish to practice and what learning objectives they intend to accomplish. Then, from another perspective, a study by Baleghizadeh, \& Karamzade (2017) revealed that EFL learners' age and their language proficiency were not determining factors in shaping their attitudes, and preferences for any of the main language class activities.

Moreover, studies comparing female and male language learners have shown several important results which are worth pondering. For instance, Shehadeh's (1999) research suggests that the language teachers must be able to create and sustain situations that provide equal chances for both males and females in all dimensions of classroom activities. Also, Grace (2000) studied the effects of first language translation on males and females who were French beginner students engaged in a computer assisted language learning (CALL) lesson. A total of 181 volunteer students from a first year French program attended two sessions in a computer lab. They were exposed to the CALL lesson, took two pretests and two posttests, completed a personality self-assessment test, and responded to a demographic questionnaire. The results showed that there is no significant difference between males and females concerning the performance on the receptive vocabulary tests. Thus, this experiment suggests that both males and females can equally benefit from CALL. Then, Phakiti's (2003) study on gender and strategy use in L2 reading, revealed that there were no gender differences as far as the reading comprehension performance and use of cognitive strategies is concerned. However, it found significantly higher use of metacognitive strategies among males. Hans and Bleses (2003) also ran a research in order to generally investigate when and how the split between male and female language preferences occurs. They studied 85 participants who were children that were all born and raised in Funen, 
Denmark. Based on the results of this study, it was claimed that 1) children in the study followed the generally believed pattern i.e. girls have significantly more standard features in their usage of language; and 2) that for Danish children, gender differences occurred at an earlier age compared to British and American children. Also, Varol and Yilmaz (2010) assume that the recent researchers have the tendency to consider equal abilities between males and females with respect to language, language learning, and various analytical and mathematical skills. However, their own study showed that regarding preferences for autonomous activities, female students apparently tried more new things in the class activities, did more non-compulsory homework, studied more English grammar on their own, and wrote down the new vocabulary more often. This shows that girls act more autonomously in and out of the classroom. In addition, Yilmaz (2010)'s study on the students' gender differences with respect to learning strategies showed that females use more effective strategies than males do. On the other hand, according to Cengizhan (2011), meta-cognitive strategies are the most frequently used vocabulary learning strategies by male language learners, and determination strategies are the most frequently used among females. Nevertheless, according to Allendorfer et al. (2011), very few gender differences in language-related activation exist when female and male learners who are matched for age and performance are directly compared. Likewise, in another study comparing male and female Malay elementary school students concerning their response to two different language teaching methods when learning English vocabulary, the author (2012) found no significant difference among boys and girls. However, another study by Baleghizadeh \& Karamzade, (2017) regarding Iranian EFL learners' perceptions of language activities in the class, revealed that females showed stronger preference toward form-oriented lessons, whereas concerning communication-oriented and control-oriented lessons, there were no significant difference in the two genders.

\section{Material and Methods}

\subsection{Introduction}

The purpose of the data collected in this study was to investigate the ideal English class from the perspective of the Taiwanese university students. Furthermore, the possible differences between those who major in English and those who major in other disciplines have been addressed. In addition, the probable differences in opinion among male and female participants have also been investigated in this research.

\subsection{Participants}

Totally, 446 students from TransWorld University in Yunlin County, Taiwan were being investigated. There were 381 (183 boys and 198 girls) non-DAFL- i.e. not EFL- majors; namely from the College of Design (47 boys, and 42 girls), College of Health Sciences (30 boys and 32 girls), College of Hospitality and Tourism ( 75 boys and 91 girls), and College of Management ( 31 boys and 33 girls). Then, there were 65 (28 boys and 37 girls) DAFL- i.e. EFL major- students. The non-DAFL students from various departments in this university have been clustered in their respective colleges because the authors could not have access to enough number of students in some departments.

\subsection{Instrument}

A 10-item multiple choice questionnaire based on (Littlewood, 2010) on the ideal classroom was modified by the authors. Different English versions of the initial questionnaire have been used elsewhere (for example Baleghizadeh \& Karamzade, 2017). Littlewood developed this questionnaire based on thematic analysis he carried out during interviews in his study. According to him, the first four items on the questionnaire are "communicative", and the other items -except for item 8- are "non-communicative". Item 8, Littlewood asserts, is neutral and might be considered to belong to either group under different circumstances.

In the present study, however, the authors made some modifications as follows:

- The most important change was to rephrase all the items into declarative, directive sentences instead of the declarative ones used previously. The logic behind this was to prevent misunderstanding on part of the participants. (As the pilot study prior to the main survey revealed, many students thought they were being asked about their existing class, and not the ideal one.) As an example, the first item "The atmosphere is relaxed." was changed to "The atmosphere must be relaxed."

- The authors thought that item 7 on the original questionnaire carried many similarities with items 5 , and 9 (all three somehow dealt with grammar). So, this idem was removed. 
- Having noticed the usage of smartphones in the classes (even often as distractions from the main flow of the class), the authors decided to replace item 7 with a question about the deliberate usage of smartphones in the class activities allowed/encouraged by the English teacher (item 10).

Then, to make sure that all participants in this study understand every single question, the modified English questionnaire (Appendix A) was translated into Mandarin Chinese by a Taiwanese expert English teacher (Appendix B). Consequently, the Chinese version of the questionnaire was used in this study. Nonetheless, when administering the questionnaire, the authors made sure that the few international students participating in this survey either received the English version, or were helped by their Chinese-speaking classmates.

\subsection{Research Questions and Hypotheses}

As mentioned before, the questionnaire items used in this research can be generally dichotomized into two categories of communicative and non-communicative activities. However, in this study, each item of the questionnaire has been examined and analyzed individually. The reason is the authors thought that each item can stand on its own; in other words, there was no specific need to cluster them into groups. Also, there were two main sections in this study: 1) investigation the gender differences among non-DAFL students, and 2) investigating the differences between DAFL students and students in the other colleges. Thus, the following general research questions and hypotheses were applied for each of the 10 items of the questionnaire:

Section 1:

(n) - Is there any significant difference between the male students' opinion about ideal English class described in item (n) of the questionnaire and that of the female students?

$\mathrm{H}_{0}(\mathrm{n})$ - There is no significant difference between the male students' opinion about ideal English class described in item (n) of the questionnaire and that of the female students.

Section 2:

(n) - Is there any significant difference between DAFL students' opinion about ideal English class described in item (n) of the questionnaire and that of non-DAFL students?

$\mathrm{H}_{0}(\mathrm{n})$ - There is no significant difference between DAFL students' opinion about ideal English class described in item (n) of the questionnaire and that of non-DAFL students.

\section{Results}

It should be mentioned here that the authors have used both descriptive and inferential statistics to discuss the data gathered in this research. We should also note that the topic of the validity of using Likert scale data in parametric analysis is a controversial one. Some advocates assert that the intervals between the Likert scale values are not equal; and thus, any mean, correlation, or other numerical values applied to them are invalid (e.g. Jamieson, 2004). On the other hand, there are those who postulate that provided that the assumptions of skewness, number of categories, etc. be met, we can validly apply parametric tests (e.g. Lubke \& Muthen, 2004). In the current study, the authors have sided with the second group. That is, when necessary, the data have been used parametrically. The reason, the authors believe, is although the intervals in Likert scales are not mathematically equal, if they are used equally among groups, the results can be correctly indicative of potential differences. The Likert scales used in this study are: strongly agree $=5$; agree $=4$; undecided $=3$; disagree $=2$; and strongly disagree $=1$.

\subsection{Section 1: Gender Differences among non-DAFL Students}

4.1.4 General Tally of the Students' Responses to Each Item of the Questionnaire

Table 2 incorporates all the non-DAFL students' responses item by item. Also, in order to have a better understanding of the responses, the numbers have been converted into percentages, and juxtaposed to each gender. 
Table 2. Students' Responses to Each Questionnaire Item Shown by Percentage

1- The atmosphere must be relaxed.

\begin{tabular}{|c|c|c|c|c|c|c|c|c|c|}
\hline \multicolumn{2}{|c|}{ Strongly agree } & \multicolumn{2}{|c|}{ Agree } & \multicolumn{2}{|c|}{ Undecided } & \multicolumn{2}{|c|}{ Disagree } & \multicolumn{2}{|c|}{ Strongly disagree } \\
\hline B 57 & G 43 & В 26 & G 45 & B 13 & G 9 & В 2 & G 3 & B 2 & $G 0$ \\
\hline
\end{tabular}

2- Some of the materials used must be from real life (such as TV, magazines).

\begin{tabular}{|c|c|c|c|c|c|c|c|c|c|}
\hline \multicolumn{2}{|c|}{ Strongly agree } & \multicolumn{2}{|c|}{ Agree } & \multicolumn{2}{|c|}{ Undecided } & \multicolumn{2}{|c|}{ Disagree } & \multicolumn{2}{|c|}{ Strongly disagree } \\
\hline В 30 & G 22 & В 28 & G 45 & B 33 & G 31 & B 7 & G 2 & B 2 & \\
\hline
\end{tabular}

3- There must be plenty of active discussion.

\begin{tabular}{|c|c|c|c|c|c|c|c|c|c|}
\hline \multicolumn{2}{|c|}{ Strongly agree } & \multicolumn{2}{|c|}{ Agree } & \multicolumn{2}{|c|}{ Undecided } & \multicolumn{2}{|c|}{ Disagree } & \multicolumn{2}{|c|}{ Strongly disagree } \\
\hline В 27 & G 14 & B 29 & G 33 & B 34 & G 43 & B 8 & G 6 & B 2 & \\
\hline
\end{tabular}

4- We must spend some time 'having fun' (such as singing songs or playing games).

\begin{tabular}{|c|c|c|c|c|c|c|c|c|}
\hline \multicolumn{2}{|c|}{ Strongly agree } & \multicolumn{2}{|c|}{ Agree } & \multicolumn{2}{|c|}{ Undecided } & \multicolumn{2}{|c|}{ Disagree } & Strongly disagree \\
\hline В 29 & G 20 & B 28 & G 33 & B 32 & G 34 & B 4 & G 7 & B 7 \\
\hline
\end{tabular}

5- The teacher must teach us new language items (such as grammar or vocabulary).

\begin{tabular}{lllllllll}
\multicolumn{2}{l}{ Strongly agree } & Agree & \multicolumn{3}{c}{ Undecided } & \multicolumn{2}{l}{ Disagree } & \multicolumn{2}{c}{ Strongly disagree } \\
B 24 G 18 & B 28 & G 43 & B 32 & G 28 & B 8 & G 8 & B 8 & G 3
\end{tabular}
B 24
G 18
B 28
G 43
B $32 \quad$ G 28
B $8 \quad$ G 8
B $8 \quad$ G 3

6- The teacher must correct most of the grammar mistakes.

\begin{tabular}{|c|c|c|c|c|c|c|c|c|c|}
\hline \multicolumn{2}{|c|}{ Strongly agree } & \multicolumn{2}{|c|}{ Agree } & \multicolumn{2}{|c|}{ Undecided } & \multicolumn{2}{|c|}{ Disagree } & \multicolumn{2}{|c|}{ Strongly disagree } \\
\hline В 33 & G 33 & В 30 & G 43 & B 23 & G 12 & B 7 & G 10 & B 7 & $C_{0}$ \\
\hline
\end{tabular}

7- A lot of time must be spent working independently of the teacher (such as in groups).

\begin{tabular}{|c|c|c|c|c|c|c|c|c|c|}
\hline \multicolumn{2}{|c|}{ Strongly agree } & \multicolumn{2}{|c|}{ Agree } & \multicolumn{2}{|c|}{ Undecided } & \multicolumn{2}{|c|}{ Disagree } & \multicolumn{2}{|c|}{ Strongly disagree } \\
\hline В 19 & G 11 & B 17 & G 32 & B 42 & G 45 & B 12 & G 8 & B 10 & \\
\hline
\end{tabular}

8- The teacher must often insist on correct pronunciation.

\begin{tabular}{|c|c|c|c|c|c|c|c|c|c|}
\hline \multicolumn{2}{|c|}{ Strongly agree } & \multicolumn{2}{|c|}{ Agree } & \multicolumn{2}{|c|}{ Undecided } & \multicolumn{2}{|c|}{ Disagree } & \multicolumn{2}{|c|}{ Strongly disagree } \\
\hline B 28 & G 24 & B 29 & G 40 & В 34 & G 27 & B 5 & G 8 & B 4 & G1 \\
\hline
\end{tabular}

9- The teacher must guide most of what the students do.

\begin{tabular}{|c|c|c|c|c|c|c|c|c|}
\hline \multicolumn{2}{|c|}{ Strongly agree } & \multicolumn{2}{|c|}{ Agree } & \multicolumn{2}{|c|}{ Undecided } & \multicolumn{2}{|c|}{ Disagree } & Strongly disagree \\
\hline В 23 & G 12 & B 25 & G 30 & B 39 & G 48 & B 9 & G 8 & B 4 \\
\hline
\end{tabular}

10- The teacher must let us use our smart phones to answer her/him.

\begin{tabular}{lllllllll}
\multicolumn{2}{l}{ Strongly agree } & Agree & \multicolumn{3}{c}{ Undecided } & \multicolumn{2}{c}{ Disagree } & \multicolumn{2}{c}{ Strongly disagree } \\
B $24 \quad$ G 10 & B 8 & G 9 & B 56 & G 52 & B 9 & G 17 & B 3 & G 12 \\
\hline Note: $B=$ Boys; $G=$ Girls & & &
\end{tabular}


Furthermore, and in order to have a better understanding as to what situations/activities are favored most by either males or females, the responses to the questionnaire items have been parametrically calculated and ranked. The results are illustrated in Table 3.

Table 3. Students' Responses to Each Item Ranked Based on Being the Most Ideal Activities

\begin{tabular}{|c|c|c|c|c|c|c|c|c|c|c|c|c|c|c|c|c|c|c|c|c|}
\hline \multirow[b]{2}{*}{ Likert } & \multicolumn{2}{|c|}{ Q.1 } & \multicolumn{2}{|c|}{ Q.2 } & \multicolumn{2}{|c|}{ Q.3 } & \multicolumn{2}{|c|}{ Q.4 } & \multicolumn{2}{|c|}{ Q.5 } & \multicolumn{2}{|c|}{ Q.6 } & \multicolumn{2}{|c|}{ Q.7 } & \multicolumn{2}{|c|}{ Q.8 } & \multicolumn{2}{|c|}{ Q.9 } & \multicolumn{2}{|c|}{ Q.10 } \\
\hline & B & $\mathrm{G}$ & B & $\mathrm{G}$ & B & $\mathrm{G}$ & B & $\mathrm{G}$ & B & $\mathrm{G}$ & B & $\mathrm{G}$ & B & G & B & $\mathrm{G}$ & $\mathrm{B}$ & $\mathrm{G}$ & B & $\mathrm{G}$ \\
\hline 5 & 525 & 430 & 280 & 215 & 250 & 135 & 265 & 195 & 220 & 175 & 300 & 325 & 175 & 110 & 260 & 240 & 210 & 120 & 220 & 100 \\
\hline 4 & 188 & 356 & 204 & 352 & 216 & 260 & 200 & 260 & 208 & 344 & 224 & 340 & 128 & 252 & 212 & 312 & 184 & 236 & 56 & 72 \\
\hline 3 & 72 & 54 & 183 & 183 & 183 & 258 & 180 & 210 & 174 & 165 & 126 & 72 & 231 & 264 & 183 & 162 & 213 & 285 & 306 & 306 \\
\hline 2 & 6 & 10 & 24 & 10 & 30 & 26 & 18 & 26 & 28 & 32 & 26 & 40 & 42 & 32 & 20 & 32 & 32 & 32 & 34 & 70 \\
\hline 1 & 4 & 0 & 3 & 1 & 3 & 7 & 11 & 11 & 15 & 6 & 12 & 4 & 18 & 9 & 7 & 2 & 8 & 4 & 6 & 23 \\
\hline Sum & 795 & 850 & 694 & 761 & 682 & 686 & 674 & 702 & 645 & 722 & 688 & 781 & 594 & 667 & 682 & 748 & 647 & 677 & 622 & 571 \\
\hline Rank & 1 & 1 & 2 & 3 & $4 / 5$ & 7 & 6 & 6 & 8 & 5 & 3 & 2 & 10 & 9 & $4 / 5$ & 4 & 7 & 8 & 9 & 10 \\
\hline
\end{tabular}

Note: $B=$ Boys; $G=$ Girls

As can be seen in Table 3, item 1 in the questionnaire has received the highest vote by both boys and girls alike; whereas, items 7, and 10 received the lowest by both genders. Also, items 2 and 6 received the second rank by both genders. Then, it is noticeable that question 9 almost received the second lowest rank by both genders. Then, for a more precise scrutiny of the results, the authors have applied the necessary statistical tests which will be discussed in the next section.

\subsubsection{Statistical Tests Used for Research Questions and Hypotheses}

A Pearson Chi-square test has been applied for each item of the questionnaire. Chi-square is used when we wish to explore the relationship between two categorical variables. Each of these variables can have two or more categories. In this study the two categorical variables for each question in each section of the study are as follows:

Section 1:

- Groups (Boys/Girls); and

- Response to questions (strongly agree/agree/undecided/disagree/strongly disagree).

Section 2:

- Groups (DAFL/non-DAFL students); and

- Response to questions (strongly agree/agree/undecided/disagree/strongly disagree).

\subsubsection{Procedure}

The most important assumption of Chi-square test is the "minimum expected cell frequency". That is, each cell should be 5 or more, or at least 80 percent of the cells should have expected frequencies of 5 or more. Because in the present study, each of the 10 questions of the multiple-choice questionnaire of the students' opinion has been examined by separate Chi-square tests, with the exception of questions number 1, and 2, the other questions met this assumption. The solution to this problem according to Clegg (1982) is to pool the adjacent cells. So, the authors merged the categories (cells) of "strongly disagree", and "disagree" for questions 1, and 2. Afterwards, a chi-square test was run for each of the 10 items in the questionnaire as summarized in Table 4 below $(\alpha \leq .05)$.

As can be seen in Table 4, the associated significance level of each chi-square test has been paired with its counterpart Pearson chi-square value. Furthermore, we know that in order to be significant, each Sig. value should be .05 or smaller. Thus, on the right column of the table, the results have been revealed. The results show that among the ten items of the questionnaire, only items 4 and 8 have been answered almost similarly (with no significant difference) by boys and girls. In other words, as for these two questions, boys and girls have very similar opinions. Thus, it can be suggested that for items 4 and 8 the null hypotheses (There is no significant difference between the male students' opinion about ideal English class described in item 4 and 8 of the questionnaire and that of the female students.) could not be rejected. This means that both genders had almost identical stands towards each of these two items. On the other hand, as for items 1, 2, 3, 5, 6, 7, 9, and 10 of the questionnaire, the difference between boys and girls has been significant, suggesting that they have significantly different ideas. Then, in order to examine the direction of this difference, the authors have calculated the sum and mean of the responses of each gender to each item parametrically based on the Likert values of 1 to 5 . Table 5 demonstrates these results. 
Table 4. Summary of the Chi-Square Test Results for Each Question

\begin{tabular}{lccl}
\hline Question & $\begin{array}{c}\text { Pearson Chi-square } \\
\text { value }\end{array}$ & $\begin{array}{c}\text { Asymp. Sig. } \\
(2 \text {-sided })\end{array}$ & $\begin{array}{l}\text { Significant or } \\
\text { Non-significant }\end{array}$ \\
\hline 1 & 15.479 & .000 & Significant \\
2 & 14.846 & .002 & Significant \\
3 & 13.312 & .010 & Significant \\
4 & 5.001 & .287 & Non-significant \\
5 & 12.902 & .012 & Significant \\
6 & 15.993 & .003 & Significant \\
7 & 16.925 & .002 & Significant \\
8 & 8.943 & .063 & Non-significant \\
9 & 10.748 & .030 & Significant \\
10 & 25.145 & .000 & Significant \\
\hline
\end{tabular}

Table 5. Likert Sum and Mean Calculated for Each Item

\begin{tabular}{|c|c|c|c|c|c|c|c|c|c|c|c|c|c|c|c|c|}
\hline & \multicolumn{2}{|c|}{ Q.1 } & \multicolumn{2}{|c|}{ Q.2 } & \multicolumn{2}{|c|}{ Q.3 } & \multicolumn{2}{|c|}{ Q.5 } & \multicolumn{2}{|c|}{ Q.6 } & \multicolumn{2}{|c|}{ Q.7 } & \multicolumn{2}{|c|}{ Q.9 } & \multicolumn{2}{|c|}{ Q.10 } \\
\hline & $\mathrm{B}$ & G & B & G & $\mathrm{B}$ & G & $\mathrm{B}$ & $\mathrm{G}$ & $\mathrm{B}$ & $\mathrm{G}$ & $\mathrm{B}$ & $\mathrm{G}$ & $\mathrm{B}$ & $\mathrm{G}$ & $\mathrm{B}$ & $\mathrm{G}$ \\
\hline Sum & 795 & 850 & 694 & 761 & 682 & 686 & 645 & 722 & 688 & 781 & 594 & 667 & 647 & 677 & 622 & 571 \\
\hline Mean & 4.34 & 4.29 & 3.79 & 3.84 & 3.72 & 3.46 & 3.52 & 3.64 & 3.75 & 3.9 & 3.24 & 3.36 & 3.53 & 3.41 & 3.39 & 2.88 \\
\hline $\begin{array}{l}\text { Mean } \\
\text { Results }\end{array}$ & \multicolumn{2}{|c|}{$\mathrm{B}>\mathrm{G}$} & \multicolumn{2}{|c|}{$\mathrm{G}>\mathrm{B}$} & \multicolumn{2}{|c|}{$\mathrm{B}>\mathrm{G}$} & \multicolumn{2}{|c|}{$\mathrm{G}>\mathrm{B}$} & \multicolumn{2}{|c|}{$\mathrm{G}>\mathrm{B}$} & \multicolumn{2}{|c|}{$\mathrm{G}>\mathrm{B}$} & \multicolumn{2}{|c|}{$\mathrm{B}>\mathrm{G}$} & \multicolumn{2}{|c|}{$\mathrm{B}>\mathrm{G}$} \\
\hline
\end{tabular}

Note: $B=$ Boys; $G=$ Girls

As shown in Table 5, boys favored questions 1, 3, 9, and 10 more than girls. This means girls favored items 2, 5, 6, and 7 more than boys. These results and the relative literature will be discussed in more details in the discussion section.

4.2 Section 2: Differences between DAFL and non-DAFL Students

As illustrated in Table 6, the associated significance level of each chi-square test has been paired with its counterpart Pearson chi-square value.

Table 6. Summary of the Chi-Square Test Results for Each Question for DAFL and Other Colleges

\begin{tabular}{|c|c|c|c|c|c|c|c|c|c|c|c|c|}
\hline & \multicolumn{3}{|c|}{ DAFL \& Design } & \multicolumn{3}{|c|}{ DAFL \& Health Sciences } & \multicolumn{3}{|c|}{$\begin{array}{c}\text { DAFL \& Hospitality and } \\
\text { Tourism }\end{array}$} & \multicolumn{3}{|c|}{ DAFL \& Management } \\
\hline Q. & $\begin{array}{l}\text { Chi-sq. } \\
\text { value }\end{array}$ & $\begin{array}{l}\text { Sig. } \\
\text { value }\end{array}$ & Result & $\begin{array}{l}\text { Chi-sq. } \\
\text { value }\end{array}$ & $\begin{array}{l}\text { Sig. } \\
\text { value }\end{array}$ & Result & $\begin{array}{l}\text { Chi-sq. } \\
\text { value }\end{array}$ & $\begin{array}{l}\text { Sig. } \\
\text { value }\end{array}$ & Result & $\begin{array}{l}\text { Chi-sq. } \\
\text { value }\end{array}$ & $\begin{array}{l}\text { Sig. } \\
\text { value }\end{array}$ & Result \\
\hline 1 & 5.388 & .146 & Non-sig. & 2.041 & .564 & Non-sig. & 1.175 & .759 & Non-sig. & 4.987 & .043 & Sig. \\
\hline 2 & 5.031 & .170 & Non-sig. & 6.767 & .080 & Non-sig. & .406 & .939 & Non-sig. & .431 & .934 & Non-sig. \\
\hline 3 & 8.738 & .033 & Sig. & 5.922 & .115 & Non-sig. & 6.016 & .111 & Non-sig. & 9.790 & .020 & Sig. \\
\hline 4 & 1.818 & .611 & Non-sig. & 10.198 & .017 & Sig. & 8.847 & .051 & Non-sig. & 13.211 & .004 & Sig. \\
\hline 5 & 12.120 & .007 & Sig. & 15.580 & .001 & Sig. & 11.946 & .008 & Sig. & 3.947 & .267 & Non-sig. \\
\hline 6 & 5.667 & .129 & Non-sig. & 7.289 & .063 & Non-sig. & 8.708 & .033 & Sig. & 13.700 & .003 & Sig. \\
\hline 7 & 6.701 & .082 & Non-sig. & 11.882 & .008 & Sig. & 10.362 & .016 & Sig. & 13.346 & .004 & Sig. \\
\hline 8 & 1.270 & .736 & Non-sig. & 4.674 & .197 & Non-sig. & 1.369 & .713 & Non-sig. & 6.486 & .090 & Non-sig. \\
\hline 9 & 11.775 & .008 & Sig. & 11.105 & .011 & Sig. & 1.928 & .588 & Non-sig. & 1.085 & .781 & Non-sig. \\
\hline 10 & 7.909 & .048 & Sig. & 4.315 & .229 & Non-sig. & 3.828 & .281 & Non-sig. & 4.981 & .034 & Sig. \\
\hline
\end{tabular}


As can be noticed from Table 6, the significant and non-significant results of the Chi-square test for each item of the questionnaire reveal as to which null hypothesis (There is no significant difference between DAFL students' opinion about ideal English class described in item (n) of the questionnaire and that of non-DAFL students.) could or could not be rejected. The table shows that DAFL students and students of Hospitality and Tourism have more common expectations. Also, they differ more from the students of Management. At the same time, the differences between DAFL students and the students from the college of Design, and the college of Health Sciences are not that noticeable because the three of them share six common non-significant items on the questionnaire.

\section{Discussion}

The present study revealed that boys and girls have almost common tendency towards English communicative language activities and non-communicative ones because they showed no significant difference in items 4 and 8 (and language games, and correct pronunciation). This is partially in tandem with the results of Baleghizadeh \& Karamzade, (2017). The findings of the present research also showed that girls are more skewed towards activities which lead to learning English correct grammar (items 6). This supports the first conclusion of the study by Hans and Bleses (2003) in that girls have significantly more standard features in their usage of language. Moreover, except for questions 4 and 8, boys and girls showed significant differences in their preference for English language activities. This finding is in contrast to the findings of Allendorfer et al. (2011), and Shirban Sasi (2012) in which the gender differences were not noticeable. Interestingly then, both genders showed the least preference towards usage of smart phones in the class activities. This is in contrast with the authors' direct observations after years of working with Taiwanese students. One possible reason might be that the students felt shy acknowledging their interest in using their smart phones in the language classes (although the questionnaires were anonymous). Moreover, both genders voted almost equally the lowest second rank to the activities independent of the teacher (item 7). This might be due to the typical teacher-centered education observed in the Taiwanese schools. Finally, both genders were by far more interested in a relaxed atmosphere in their English classes which can be indicative of the necessity of avoiding tensions or probable embarrassing situations which can occur in any language class.

Then, as for the comparison of the EFL-major and non-EFL-major students, we witnessed almost a little difference between DAFL students and students of the college of Design, and the college of Health Sciences; almost no difference between DAFL and students from college of Hospitality and Tourism; and a significant difference between DAFL and Management students.

\section{Conclusion}

The current study investigated Taiwanese university students' preference as to what language activities constitute an ideal English class. Boys and girls revealed some commonalities, even though their differences were more noticeable. The authors believe that the results of this research and similar studies in the future can prove helpful to decision makers and education authorities. Accordingly, the authors would like to suggest the following topics for further investigations in future studies in Taiwan or elsewhere:

- Similar surveys covering more participants from other universities;

- Similar surveys targeting EFL teachers;

- Similar surveys targeting high school (or elementary) students;

- Studies which apply open-ended interviews in order to precisely see why students prefer certain activities for their ideal English class;

- Contrastive analysis between the ideal English class activities and those in other languages.

\section{References}

Allendorfer, J. B., Lindsell, C. J., Siegel, M., Banks, C. L., Vannest, J., \& Holland, S. K., et al (2012). Females and males are highly similar in language performance and cortical activation patterns during verb generation. Cortex, 48(9), 1218-1233. https://doi.org/10.1016/j.cortex.2011.05.014

Baleghizadeh, S., \& Karamzade, T. (2017). Iranian EFL learners' perceptions of various language activities in an ideal English class. MEXTESOL Journal, 41(1), 1-14. 
Cengizhan, L. (2011). Vocabulary learning strategies: a case of Edirne Anatolian high school. Procedia Social and Behavioral Sciences, 15, 1870-1874. https://doi.org/10.1016/j.sbspro.2011.04.018

Clegg, F. (1982). Simple statistics: A course book for the social sciences. Cambridge: Cambridge University Press.

Grace, C. A. (2000). Gender differences: vocabulary retention and access to translations for beginning language learners in CALL. The Modern Language Journal, 84(2), 214-224. https://doi.org/10.1111/0026-7902.00063

Green, J. M. (1993). Student attitudes towards communicative and non-communicative activities: Do enjoyment and effectiveness go together? Modern Language Journal, $77(1)$, 1-10. https://doi.org/10.1111/j.15404781.1993.tb01938.x

Hans, J. L., \& Bleses, D. (2003). Gender differences in young children's speech: the acquisition of sociolinguistic competence. International Journal of Applied Linguistics, 13(2), 222-233. https://doi.org/10.1111/1473-4192.00045

Jamieson, S. (2004). Likert scales: how to (ab) use them. Medical Education, 38, 1212-1218. https://doi.org/10.1111/j.1365-2929.2004.02012.x

Kaushanskaya, M., Marian, V., \& Yoo, J. (2011). Gender differences in adult word learning. Acta Psychologica, 137, 24-35. https://doi.org/10.1016/j.actpsy.2011.02.002

Littlewood, W. (2010). Chinese and Japanese students' conceptions of 'the ideal English lesson'. RELC Journal, 41(1), 46-58. https://doi.org/10.1177/0033688210362622

Lubke, G. H., \& Muthen, B. O. (2004). Applying Multigroup Confirmatory Factor Models for Continuous Outcomes to Likert Scale Data Complicates Meaningful Group Comparisons. Structural Equation Modeling, 11, 514-534. https://doi.org/10.1207/s15328007sem1104_2

MacIntyre, P.D., \& Baker, S. C. (2002). Sex and age effects on willingness to communicate, anxiety, perceived competence, and L2 motivation among junior high school French immersion students. Language Learning, 52(3), 537-564. https://doi.org/10.1111/1467-9922.00194

Nunan, D. (1996). Towards autonomous learning: Some theoretical, empirical and practical issues. In R. Pemberton, E. S. L. Li, W. F. Or \& H. D. Pierson (Eds.), Taking control: Autonomy in language learning (pp. 13-26). Hong Kong: Hong Kong University Press.

Phakiti, A. (2003). A closer look at gender and strategy use in L2 reading. Language Learning, 53(4), 649-702. https://doi.org/10.1046/j.1467-9922.2003.00239.x

Rao, Z. (2002). Chinese students' perception of communicative and non-communicative activities in EFL classroom. System, 30(1), 85-105. http://dx.doi.org/10.1016/S0346-251X(01)00050-1

Sampson, R. J. (2010). Student-negotiated lesson style. RELC Journal, 41(3), 283-299. https://doi.org/10.1177/0033688210380555

Shehadeh, A. (1999). Gender differences and equal opportunities in the ESL classroom. ELT Journal, 53(4), 256-261. https://doi.org/10.1093/elt/53.4.256

Shirban Sasi, A. (2012). The effects of applying Pictologics (PLS) method on English vocabulary learning by Malaysian year six primary school students. Unpublished Ph. D. thesis, University Sains Malaysia, Malaysia.

Shirban Sasi, A. (2014). Iran and Asia: the New Stage of SMEs in Malaysia, Taiwan, China, and Japan. 2014 International Conference on Asian Regional Economy and Local Industry Development, TransWorld University, Douliu, Taiwan, Nov., 4-6.

Spratt, M. (2001). The value of finding out what classroom activities students like. RELC Journal, 32(2), 80-101. https://doi.org/10.1177/003368820103200206

Taiwan Language Exchange - Taiwanese Language Partners (2018). Retrieved in Feb. 2018 from https://www.mylanguageexchange.com/Search.asp?selCountry=90\&lang=en

Varol, B., \& Yilmaz, S. (2010). Similarities and difference between female and male learners: Inside and outside class autonomous language learning activities. Procedia Social and Behavioral Sciences, 3, 237-244. https://doi.org/10.1016/j.sbspro.2010.07.038

Yang, Y. (2001). Sex and language proficiency level in color-naming performance: an ESL/EFL perspective. International Journal of Applied Linguistics, 11(2), 238-256. https://doi.org/10.1016/j.sbspro.2010.03.084 
Yilmaz, C. (2010). The relationship between language learning strategies, gender, proficiency and self-efficiency beliefs: a study of ELT learners in Turkey. Procedia Social and Behavioral Sciences, 2, 682-687.

\section{Appendix A}

\section{The Ideal English Lesson Questionnaire}

Sex: Male

Female

Instruction: Please read each statement below carefully and choose your opinion regarding the characteristics of an ideal English lesson. Please choose only one of (strongly agree, agree, undecided, disagree, strongly disagree) responses. Thank you.

\section{In my ideal English lesson:}

1- The atmosphere must be relaxed.

strongly agree $\square \quad$ agree $\square$ undecided $\square \quad$ disagree $\square \quad$ strongly disagree $\square$

2- Some of the materials used must be from real life (such as TV, magazines).

strongly agree $\square \quad$ agree $\square \quad$ undecided $\square \quad$ disagree $\square \quad$ strongly disagree $\square$

3- There must be plenty of active discussion.

strongly agree $\square \quad$ agree $\square \quad$ undecided $\square \quad$ disagree $\square \quad$ strongly disagree $\square$

4- We must spend some time 'having fun' (such as singing songs or playing games).

strongly agree $\square \quad$ agree $\square \quad$ undecided $\square \quad$ disagree $\square \quad$ strongly disagree $\square$

5- The teacher must teach us new language items (such as grammar or vocabulary).

strongly agree $\square \quad$ agree $\square \quad$ undecided $\square \quad$ disagree $\square \quad$ strongly disagree $\square$

6- The teacher must correct most of the grammar mistakes.

strongly agree $\square \quad$ agree $\square \quad$ undecided $\square \quad$ disagree $\square \quad$ strongly disagree $\square$

7- A lot of time must be spent working independently of the teacher (such as in 
groups).

strongly agree $\square \quad$ agree $\square \quad$ undecided $\square \quad$ disagree $\square \quad$ strongly disagree $\square$

8- The teacher must often insist on correct pronunciation.

strongly agree $\square \quad$ agree $\square \quad$ undecided $\square \quad$ disagree $\square \quad$ strongly disagree $\square$

9- The teacher must guide most of what the students do.

strongly agree $\square \quad$ agree $\square \quad$ undecided $\square \quad$ disagree $\square \quad$ strongly disagree $\square$

10- The teacher must let us use our smart phones to answer her/him.

strongly agree $\square \quad$ agree $\square \quad$ undecided $\square \quad$ disagree $\square \quad$ strongly disagree $\square$

\section{Appendix B}

\section{理想的英语課問卷調查}

\section{你的科系名稱}

性別：男性 $\square$ 女性 $\square$

(說明)：請仔細閱讀以下每個陳述並選出你對於理想英语課的特性的意見 請單選作答。謝謝你。

\section{我理想的英语課}

1. 氣氛一定是輕鬆愉悅的

非常同意 $\square$ 同意 $\square$ 沒意見 $\square$ 不同意 $\square$ 非常不同意 $\square$

2. 一些所使用的教材一定是來自於真實的生活如電視或雜 誌

非常同意 $\square$ 同意 $\square$ 沒意見 $\square$ 不同意 $\square$ 非常不同意 $\square$

3. 一定要有一些積極的討論 


\section{非常同意 $\square$ 同意 $\square$ 沒意見 $\square$ 不同意 $\square$ 非常不同意 $\square$}

4. 學生一定要花一些時間玩樂如唱歌和玩遊戲

\section{非常同意 $\square$ 同意 $\square$ 沒意見 $\square$ 不同意 $\square$ 非常不同意 $\square$}

5. 老師一定要教學生新的語言項目如文法或單字

非常同意 $\square$ 同意 $\square$ 沒意見 $\square$ 不同意 $\square$ 非常不同意 $\square$

6. 老師一定要紅正一些文法上的錯俁

\section{非常同意 $\square$ 同意 $\square$ 沒意見 $\square$ 不同意 $\square$ 非常不同意 $\square$}

7. 學生們一定要花多點時間不靠老師獨立地完成工作如小 組合作

非常同意 $\square$ 同意 $\square$ 沒意見 $\square$ 不同意 $\square$ 非常不同意 $\square$

8. 老師一定要時常強調正確的發音

非常同意 $\square$ 同意 $\square$ 沒意見 $\square$ 不同意 $\square$ 非常不同意 $\square$

9. 老師一定要指導大部份學生所做的事

非常同意 $\square$ 同意 $\square$ 沒意見 $\square$ 不同意 $\square$ 非常不同意 $\square$

10. 老師一定要讓學生用智慧型手機來回答他的問題

非常同意 $\square$ 同意 $\square$ 沒意見 $\square$ 不同意 $\square$ 非常不同意 $\square$

